\title{
Women and the Wiener Werkstätte
}

\author{
A Review of: Die Frauen der Wiener Werkstätte / Women Artists \\ of the Wiener Werkstätte, edited by Christoph Thun-Hohenstein, \\ Anne-Katrin Rossberg, and Elisabeth Schmuttermeier, Basel: \\ Birkhäuser: 2020. 288 pp. ISBN: 978-3035622119.
}

\section{Julia Secklehner (secklehner@phil.muni.cz)}

Department of Art History, Masaryk University, Brno, Czech Republic

\section{Keywords}

Wiener Werkstätte; women designers; applied arts; Vienna; Vally Wieselthier; Martha Alber; Valerie Jahn; Koloman Moser; Josef Hoffmann;

https://doi.org/10.5817/AEC2021-1-8 


\section{Women and the Wiener Werkstätte}

\section{A Review of: Die Frauen der Wiener Werkstätte / Women Artists of the Wiener Werkstätte, edited by Christoph Thun-Hohenstein, Anne-Katrin Rossberg, and Elisabeth}

Schmuttermeier, Basel: Birkhäuser: 2020. 288 pp. ISBN: 978-3035622119..

\section{Julia Secklehner}

In Autumn 2020, the Museum of Applied Arts in Vienna (MAK) was due to open an exhibition that shed new light on women's contributions to the Wiener Werkstätte (Viennese Workshops) design brand. Due to the current pandemic, the exhibition has had to be postponed to next year (21 April - 3 October 2021), but the accompanying bi-lingual catalogue was published to coincide with the original planned dates. With lavishly illustrated essays by experts at the MAK and scholars from elsewhere, and over one hundred short biographies of women artists, the catalogue is a rich resource that credits women artists' contributions to the Wiener Werkstätte from multiple perspectives.

In line with other publications from recent years, such as Textile Modernism (2019) or Bauhaus Women (2019), the essays seek to restore the role of women in one of the major modernist art and design institutions, whose significance has often been tied to the work of a handful of male artists and designers. ${ }^{1}$ In the case of the Wiener Werkstätte, these male figures are Josef Hoffmann and Koloman Moser, who built a network between the Museum for Art and Industry, the School of Applied Arts and the Wiener Werkstätte as pillars of Viennese modern design. While these men obviously take a back seat in the present publication, Hoffmann's influence still emerges as central to the professional careers of many Wiener Werkstätte women artists: between 1915/16 and 1930 no other design school in the region boasted more female students, and over a third of them began to work for the Wiener Werkstätte. Presented in a contextualising chapter by Elisabeth Kreuzhuber, such statistics frame the catalogue's narrative. Beyond the meticulous archival work that this research is based on, these 'hard facts' also imply that the catalogue does more than to simply to reinsert forgotten artists and designers into the Wiener Werkstätte narrative: the sheer number of women artists included in the catalogue indicates that only with their inclusion can we gain a more complete image of the Wiener Werkstätte.

Indeed, the essays that focus on individual workshops / departments within the Wiener Werkstätte, such as toy design and ceramics (both by Megan Brandow-Faller), fashion and textiles (Angela Völker/ Lara Steinhäußer), and postcard design (Elisabeth Schmuttermeier), show that, overall, women represented a significant part of the creative workforce behind the Wiener Werkstätte as a commercial venture. The rich illustrations accompanying the essays also attest to this. A particularly well-chosen example to introduce women's design as part of

1) Textile Moderne / Textile Modernism, ed., Burcu Dogramaci, Vienna: Böhlau, 2019; Elizabeth Otto and Patrick Rössler, Bauhaus Women: A Global Perspective, London: Bloomsbury, 2019. 
Viennese modernism is the juxtaposition of a blouse with a fabric design by Martha Alber, Gustav Klimt's portrait of Johanna Staude wearing the blouse, and a greeting card with the same pattern (p. 110). In keeping with the notion of the Gesamtkunstwerk, the catalogue thus makes clear that women's contributions to Viennese modernism are still hidden in plain sight. It offers convincing visual arguments, too, including countless design drafts and photographs, as well as dividers between each essay, reprinting diverse fabric patterns by some of the women designers discussed in the catalogue.

Even though the majority of women were trained in realms of design that were deemed 'feminine' (soft furnishings and tableware), the catalogue underlines that the Wiener Werkstätte also gave exceptional provision to women's artistic experimentation. This is most evident with the Artist's Workshop, founded in 1916 as a studio where artists could work without restrictions. An essay by Anne-Katrin Rossberg on this topic highlights the extent to which the workshop was a central feature for women's creative production, and the opportunities it gave for free experimentation strongly supported the artistic development of Mehrfachkünstlerinnen ('multivalent women artists,' as Brandow-Faller translates it) such as Vally Wieselthier, Maria Likarz and Martha Alber.

The crux to this relative freedom, Rossberg points out, were its ties to a competitive market: as 'an incentive to produce marketable objects,' the Wiener Werkstätte operated on the basis of a system of premiums, and even dismissed the designer Hilda Jesser for demanding a fixed salary in 1921 (p. 149). Revelations like this would offer an entry into more critical analyses about women's position in the Wiener Werkstätte, beginning with the question as to how far the demands of a commercial venture dictated women's opportunities, emancipation and position as working women. This also affects the role of women working in other areas of the Wiener Werkstätte business, which are only mentioned briefly, including its managing director Valerie Jahn (1929-1931), or the artist Margaret Bilger who worked for the company as a salesgirl (p. 21).

The catalogue essays show that the Wiener Werkstätte's support for a whole generation of women artists based on demands for a highly skilled workforce created its own 'type' of modern woman: the Kunstgewerblerin ('female decorative artist'). That this was not an easy position to hold is emphasised in the majority of contributions to this catalogue. Repeatedly referring to attacks by Adolf Loos and Arthur Rössler, among others, on the 'Wiener Weiberkunstgewerbe' a demeaning play on the Wiener Werkstätte brand name by the painter Julius Klinger (the term is rendered here with the Americanism 'Viennese Broad's Applied Art'), they show that the link between a female creative workforce and the applied arts as a 'dilettante minor art' produced by haute-bourgeois women faced strong opposition from central figures of Viennese modernism. Yet, with the exception of Brandow-Faller's essay on ceramic sculpture, which argues that Vally Wieselthier and her students forged their own 'feminine' strand of expression with brightly coloured ceramic sculpture, it is unclear how, or if at all, these criticisms might have impacted on women's work at the Wiener Werkstätte overall.

Throughout the catalogue, the opposition between emancipated women artists and established male critics of Viennese modernism appears to be irreconcilable. This narrative underlines the difficult circumstances in which the women of the Wiener Werkstätte 
sought to forge careers for themselves. Most crucially, and with the exception of the 'female expressionism' of Wieselthier and her students, the question remains as to what bigger impact the strong female representation in the Wiener Werkstätte might have on our understanding of Viennese modernism today. By focusing on individual aspects of the Wiener Werkstätte, readers gain a closer view of what women's involvement looked like, but it is unclear how, based on this, albeit convincing evidence, we should be seeing Viennese modernism differently. Indeed, this question is complicated further by the concluding part of the catalogue, the biographies.

They number one hundred and twenty-eight in total and, focusing on basic biographical data, including what and when individual artists contributed to the Wiener Werkstätte, they offer a wealth of information that underlines the diversity of the women creating for the Wiener Werkstätte brand. Coming to Vienna from across the Empire, as well as from abroad, and hailing from different (though mostly privileged) social backgrounds, the biography section shows that there was no such 'type' as the Kunstgewerblerin. Rather, and Kreuzhuber suggests this in her essay, the Kunstgewerblerin was a profession that slowly paved women's way into a modern market economy from the late nineteenth century onwards. As a basic category overall, therefore, the 'woman artist of the Wiener Werkstätte' is rather more complex than the linear narratives of individual departments reveal. Comprising the final part of the catalogue, the biographies are well placed for precisely this reason, offering not a conclusion but, rather, an impetus for further research on a topic that is far from exhausted.

Overall, the catalogue leaves no doubt that women contributed significantly to the Wiener Werkstätte brand throughout its twenty-year existence. This alone makes Women Artists of the Wiener Werkstätte a publication of note, with the planned exhibition still to look forward to. At the same time, the arrangement of the new findings it offers would have benefitted from a different structure. Though visually impressive and giving new insights into a widely understudied topic, the catalogue predominantly focuses on linear narrative accounts. For example, Angela Völker's comparison between the textile departments of the Wiener Werkstätte and the Bauhaus gives a parallel, chronological account of the history and ideas of both departments and shows that there were personal contacts and exchanges between them, led by figures such as Hoffmann and Johannes Itten. However, the narrative focuses on factual information only, without providing a wider critical assessment of what the significance of such connections (or the lack thereof) might be. While such a positivistic approach may aim to engage a broader audience in line with the pressures to curate ever-more popular exhibitions, it offers little broader contextualisation of the Wiener Werkstätte overall, thereby making it of more interest for the specialist reader.

Given the substantial groundwork Women Artists of the Wiener Werkstätte has laid out, it bears the potential to spearhead a rethinking of Viennese modernism as a more inclusive phenomenon - all the more so as the product of a central institution such as the MAK. To advance this process, however, it is necessary to engage more closely, and more critically, in the points raised by the catalogue, asking questions such as: What potential lies in examining the role of the Kunstgewerblerin as a modern artistic profession? How might better understanding of women's contributions to the Wiener Werkstätte challenge existing conceptions of Viennese modernism? And how would this modify our understanding of figures that have hitherto 
been central, such as Hoffmann? In light of these questions, the catalogue serves both as a sourcebook and a starting point, anticipating further studies to assess the broader impact of women's contributions to the Wiener Werkstätte within the broader field of (Viennese) modernism.

The MAK is running an open call for information on women artists involved in the Wiener Werkstätte on their website. 
